\title{
The usefulness of capillaroscopy for assessment of microcirculation disturbances during treatment
}

\section{ABSTRACT}

Capillaroscopy is a non-invasive method enabling the assessment of microcirculation in patients with Raynaud's phenomenon. The examination has been used for early diagnosis of systemic sclerosis and diseases from the scleroderma spectrum and for assessment of systemic sclerosis activity as well as for monitoring and evaluation of the efficacy of therapy. Vasodilators applied in the treatment of vascular disorders during systemic sclerosis were demonstrated to significantly improve the capillaroscopy images, expressed as an increased number of capillaries and reduced disorganisation of vascular drawings.

Forum Reumatol. 2019, tom 5, nr 2: 65-69

Key words: systemic sclerosis; capillaroscopy; vasodilators

\section{INTRODUCTION}

Capillaroscopic examination is a non-invasive method consisting in imaging capillaries of the papillary layer of skin within the nailfold of fingers or toes under a stereo microscope or a videocapillaroscope. It is particularly useful in early diagnosis of the systemic sclerosis ( $\mathrm{SSc}$ ), resulting from morphological and functional disorders of tiny blood vessels, referred to as microangiopathy. Capillaroscopy may not only be applied to diagnose systemic sclerosis $(\mathrm{SSc})$ at its early stage but also, through imaging of micro-circulation of nailfold vessels, it may also be used to evaluate the development of major organ vascular complications related to the course of systemic sclerosis (SSc), such as pulmonary arterial hypertension, fingertip ulcerations and scleroderma renal crisis. Moreover, by means of changes manifested in the study, it is possible to evaluate a patient's activity and a degree of internal organ involvement, as well as to monitor the effects of the therapy.

\section{CAPILLAROSCOPY EVALUATION OF MICROCIRCULATORY DISORDERS}

Capillaroscopy examination of the nailfold vessels is used in differential diagnostics between primary Raynaud's symptom and micro-circulatory disorders in the symptom of secondary Raynaud's, which causes systemic connective tissue diseases, especially systemic sclerosis (SSc), but the scleroderma-related diseases, such as dermatomyositis, polymyositis, mixed connective tissue disease or undifferentiated connective tissue disease [1]. Capillaroscopy image in healthy subjects is characterised by a regular, parallel arrangement of capillaries. One dermal papilla should include from one to three vessels papillae, there should be from one to three winding vessels and their diameter should not exceed $30 \mu \mathrm{m}$ (Fig. 1). Capillaroscopy of the systemic sclerosis course manifests characteristic disorders in micro-circulation, referred to as microangiopathy, which is typical for scleroderma-related diseases. The term of microangiopathy includes: dilatation of vascular loops causing the
Correspondence address: dr hab. n. med. Ewa Wielosz Chair and Clinic of Rheumatology and Connective Tissue Diseases, Medical University of Lublin e-mail: ewa.wielosz@wp.pl 


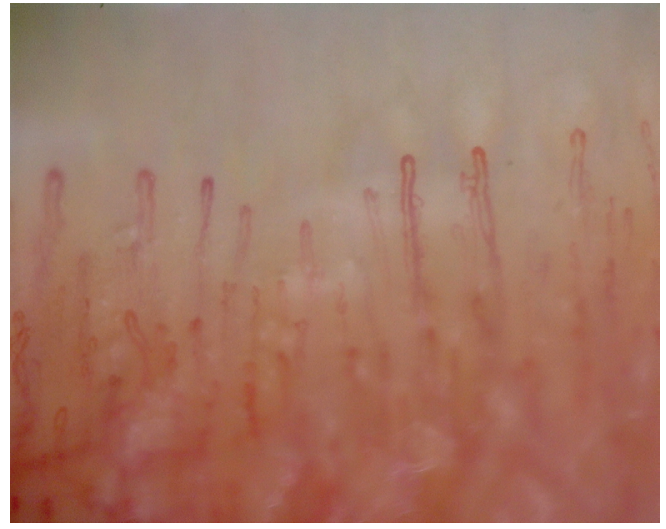

Figure 1. Correct capillaroscopy image

formation of mega-capillaries, reduction of the number of vessels, with a vascular areas, presence of branching loops and cap-shaped micro-hemorrhages, and disorganisation of the vascular imaging [2]. Cutolo et al. divided capillaroscopic changes according to the duration of systemic sclerosis (SSc) [3]. Early-, active- and late-stage changes were distinguished. This classification presented megacapillaries to be typical for an early stage of scleroderma microangiopathy and are less common at a late stage of the disease. As the disease progresses, reduction of vessels, presence of a vascular areas and vascular growth, typical for active changes, are observed. In the late stage of systemic sclerosis ( $\mathrm{SSc}$ ), megacapillaries are less frequent, whilst a vascular areas and branched vessels are the dominant ones [3] (Fig. 2 and 3). Evaluation of the microangiopathy type is particularly important, since its basis provides a possibility of determining an activity and progression of the disease, and in many cases, evaluating the prognosis. It has been shown that a rapid reduction of the number of vessels, later corresponding to scleroderma microangiopathy in capillaroscopy, is a factor of worse prognosis, increased progression of the disease and higher degree of internal organs involvement [4].

Great number of reports, demonstrating a correlation between capillaroscopic changes and the internal organ involvement, are available. The rapid dynamics of changes, with the tendency to reduce the number of vessels and develop late-stage microangiopathy, especially during the first 3 years of the disease, correlates with the more severe course of systemic sclerosis (SSc), the risk of interstitial changes in the lungs and vascular complications, such as fingertip ulcerations [5, 6]. Paxton et al., by means of the Medline and Embase databases

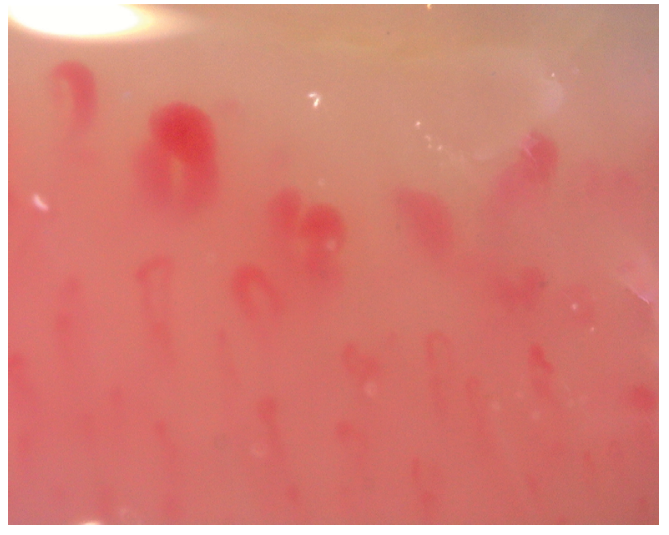

Figure 2. Active scleroderma microangiopathy

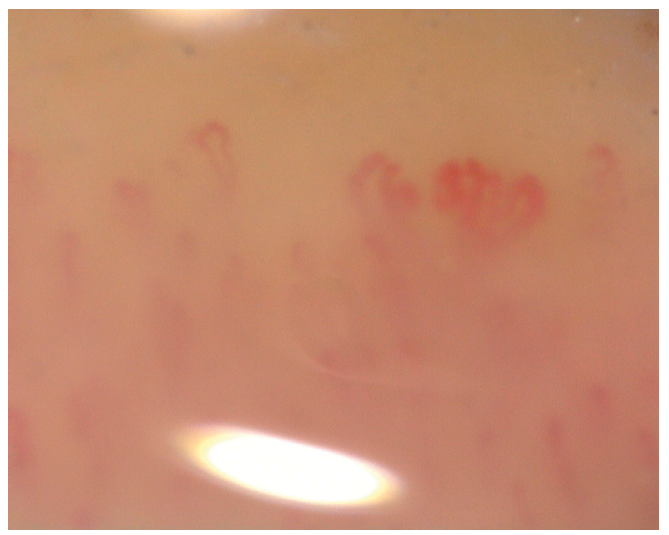

Rycina 3. Late scleroderma microangiopathy

literature analysis, demonstrated a correlation between changes in capillaroscopy (loss of capillaries in particular) and complications in the disease course, such as fingertip ulcerations, calcifications and pulmonary arterial hypertension [7]. Capillaroscopic examination also enables to predict the risk of vascular complications (e.g., fingertip ulcerations). Ulcer development index $\mathrm{M} \times \mathrm{D}: \mathrm{N} 2$ is used for this purpose, where $M$ is the number of megacapillaries per $1 \mathrm{~mm}, \mathrm{D}$ is a diameter of megacapillaries - the widest capillary dimension, $\mathrm{N}$ is a total number of capillaries - the number of vascular loops in $1 \mathrm{~mm}$. It was shown that if the index exceeds 2.96 , this result correlates with an increased risk of the development of ulcerations within 3 months [8].

\section{PROCEDURE IN MICROCIRCULATORY DYSFUNCTIONS IN SYSTEMIC SCLEROSIS AND SCLEROTERMA-RELATED DISEASES}

Remodelling of the vessel wall, which contributes to the development of microangiopathy, is observed in the course of the disease. The earliest damage is caused to endothelial 
cells. Activated endothelial cells excessively release vasoconstrictive factors such as endothelin 1 (ET-1) or vascular endothelial growth factor (VEGF). Deficiency of vasodilatory factors such as prostacyclin and nitric oxide is also detected. Shrinkage and proliferation of the vessel wall is the effect of an increased ET-1 release and deficiency of prostacyclin and nitric oxide [9]. Drugs, which are currently administered in microcirculatory disorders in the course of systemic sclerosis, stimulate the pathway of prostacyclin or nitric oxide or inhibit the pathway of ET-1. The first group consists of synthetic prostacyclins and their analgesics: epoprostenol, treprostinil or iloprost, or prostacyclin receptor agonists - selexipag. The latter group inhibits decomposition or increases production of nitric oxide. Vasodilatation effect of the nitric oxide is activated when the participation of guanyl cyclase and an increase in the cyclic activity of guanosine-3', 5'-monophosphate (cGMP) are observed. It was demonstrated that the activity of phosphodiesterase type 5 - enzyme decomposing cyclic GMP in patients with $\mathrm{SSc}$ - is increased, which causes an increased decomposition of nitric oxide. In order to inhibit the nitric oxide decomposition, phosphodiesterase type 5 inhibitors, such as sildenafil or tadalafil are used to treat vascular disorders. Nitric oxide production can also be increased by using guanyl cyclase activators (riociguat). The last group of drugs used in vascular disorders inhibits the release of ET- 1 by blocking the receptors for endothelin type A and $\mathrm{B}$ on the smooth muscle cells - these are non-selective and selective (macitentan, ambrisentan, bosentan) inhibitors of the ET1-A receptor [10]. These drugs are particularly suitable for the treatment of the Raynaud's symptom episodes in patients with systemic sclerosis ( $\mathrm{SSc}$ ), fingertip ulcerations, pulmonary arterial hypertension, or prevention of the new finger ulcers in patients with SSc and scleroderma-related diseases [11]. As a consequence, these drugs, demonstrating a strong vasodilatory, antiproliferative, cytoprotective and antithrombotic effect, inhibit remodeling in the vessel wall. Therefore, use of the vasodilatory preparations significantly changes the image of vessels in capillaroscopic examination.

\section{CHANGES IN MICROCIRCULATION IN CAPILLAROSCOPIC IMAGING IMPACTED BY THE APPLIED THERAPIES}

There are many written reports presenting the dynamics of changes in microcirculation assessed on the basis of capillaroscopic examination under the influence of the applied vasodilatory treatment. These studies suggest that capillaroscopy plays an important role in monitoring the efficacy of therapy in patients with systemic sclerosis. One of the studies prospectively compared a capillaroscopic image in the group of 9 patients with systemic sclerosis (SSc) undergoing the one-year bosentan therapy with a group of of 9 patients suffering from systemic sclerosis (SSc) who were being administered illoprost for one year. After the 12-month bosentan therapy the capillaroscopic image changed from the late-stage to the active-stage of microangiopathy in 7 patients and no changes in the image were detected in 2 subjects - the observed changes were of the active-stage microangiopathy and they remained that way. In the group of patients treated with iloprost, capillaroscopic changes did not change in the course of annual therapy. It was demonstrated that long-term administration of ET-1 receptor blockers changes the capillaroscopic image, which is reflected in an increased number of capillaries, reduced number of branched vessels and reduced disorganisation of the vascular image, and thus it stabilises the micro-circulation evaluated by the capillaroscopic examination [12].

Another study evaluated retrospectively the effect of bosentan and sildenafil therapy and a combined therapy on the frequency of Raynaud's symptom attacks and the image of microcirculatory changes in capillaroscopy. 123 patients with systemic sclerosis (SSc) were examined and the capillaroscopic image was evaluated at the initial stage, after 3 and 6 months of the treatment. It was concluded that the combined therapy had a significantly better vascular effect than the separate use of these drugs and that the capillaroscopic image demonstrated mainly a decrease in a number of late-stage microangiopathies and de-remodeling of small vessels [13].

Another study assessed an impact of iloprost as well as iloprost and bosentan on capillaroscopic changes in patients with systemic sclerosis. Influence of the treatment on the scleroderma microangiopathy was evaluated by means of capillaroscopic risk index of the skin ulceration development in patients with systemic sclerosis. At the first visit following the one-year treatment capillaroscopic examination was performed in $95 \mathrm{SSc}$ patients who had been undergoing the iloprost and the combined therapy. It was indicated that efficacy of the bosentane- iloprost combined therapy in 
the treatment of fingertip ulcerations in patients with systemic sclerosis (SSc) was higher and the reduction of ulcerations was a consequence of an improved microcirculatory changes in a capillaroscopic image, of a decreased vascular disorganisation and an improved capillaroscopic skin risk index of ulceration development impacted by the applied treatment [14]. On the other hand, Cutolo et al. showed a significant increase in the number of vessels and a slight decrease in the a vascular areas in the capillaroscopic examination in patients with systemic sclerosis during the 3-year therapy with bosentan and iloprost [15]. Similar results were obtained by Trombetta et al. during the 4-year period of the combined therapy [16]. There are also reports concerning microcirculatory changes demonstrated in the capillaroscopic examination in patients with severe diffuse systemic sclerosis who had received an autologous bone marrow stem cell transplantation. In the group of 16 patients with a diffuse type of systemic sclerosis, diagnosed with the late-stage scleroderma microangiopathy, autologous bone marrowa stem cell transplantation was parformed in 6 patients and cyclophamide was administered in 10 patents in a dose of $1 \mathrm{~g} /$ month for 6 months and subsequently of $50 \mathrm{mg} /$ day p.o. for six months. Capillaroscopic examinations were performed every 3 months. During the 2-year observation changes from the late-stage to the active-stage microangiopathy were detected in the capillaroscopic image, after only 3 months following the transplantation. In the course of treatment, no changes in capillaroscopy were observed in patients receiving cyclophosphamide [17]. Dynamics and significant improvement of capillaroscopic changes impacted by the ap- plied treatment can also be observed in other connective tissue systemic diseases, such as dermatomyositis or polyamositis. It was demonstrated that the immunosuppressive therapy significantly increases the density of capillaries and improves their distribution the group of patients with microangiopathy typical for systemic sclerosis $[18,19]$.

\section{SUMMARY}

Capillaroscopic examination is a non-invasive study enabling the evaluation of microcirculatory disorders, which apart from early diagnosis of systemic sclerosis and diseases from the scleroderma spectrum, as well as an evaluation of disease activity and the degree of internal organ involvement, may be used in monitoring and evaluating effectiveness of treatment. Vasodilators used in the treatment of systemic sclerosis and scleroderma-related diseases significantly alter the capillaroscopic image, which is expressed by a higher number of capillaries, reduced vascular disorganisation and the inhibition of vessel wall modelling. The cardiovascular-drug combined therapy significantly affects both the improvement of micro-circulation assessed in a capillaroscopic examination and the reduction of capillaroscopic skin ulcer risk index, which in consequence significantly prevents finger ulcerations and other vascular complications in systemic sclerosis. In the group of patients with the scleroderma-related microangiopathy diseases (dermatomyositis and polymyositis) immunosuppressive therapy significantly influences the improvement of capillaroscopic changes.

\section{Piśmiennictwo}

1. Etehad Tavakol M., Fatemi A., Karbalaie A. i wsp. Nailfold capillaroscopy in rheumatic diseases: which parameters should be evaluated? Biomed. Res. Int. 2015; 2015: 974530.

2. Lambova S., Hermann W., Muller-Ladner U. nailfold capillaroscopy - its role in diagnosis and differential diagnosis of microvascular damage in systemic sclerosis. Curr. Rheumatol. Rev. 2013; 9: 254-260.

3. Cutolo M., Sulii A., Pizzorni C. i wsp. Nailfold video capillaroscopy assesment of microvascular damagei systemic sclerosis. J. Rheumatol. 2000; 27: 155-160.

4. Emrani Z., Karbalaie A., Fatemi A. i wsp. Capillary density: An important parameter in nailfold capillaroscopy. Microvasc. Res. 2017; 109: 7-18.

5. Bredemeier M., Xavier R.M., Capobianco K.G. iwsp. Nailfold capillary microscopy can suggest pulmonary disease activity in systemic sclerosis. J. Rheumatol. 2004; 31 : 286-294.
6. Smith V., Decuman S., Sulli A. i wsp. Do worsening scleroderma capillaroscopic patterns predict future severe organ involvement? A pilot study. Ann. Rheum. Dis. 2012; 71: 1636-1639.

7. Paxton D., Pauling J.D. Does nailfoldcapillaroscopy help predict future outcomes in systemic sclerosis? A systematic literature review. Semin. Arthritis Rheum. 2018; pii: S0049-0172(17)30765-5. doi: 10.1016/j.semarthrit.2018.02.005.

8. Sebastiani M., Manfredi A., Vukatana G. i wsp. Predictive role of capillaroscopic skin ulcer risk index in systemic sclerosis: a multicentre validation study. Ann. Rheum. Dis. 2012; 71: 67-70.

9. Penn H., Quillinan N., Khan K. i wsp. Targeting the endothelin axis in scleroderma renal crisis: rationale and feasibility. QJM 2013; 106: 839-848.

10. Sahni S., Ojrzanowski M., Majewski S. i wsp. Pulmonary arterial hypertension: a current review of pharmaco- 
logical management. Pneumonol. Alergol. Pol. 2016; 84: 47-61.

11. Kowal-Bielecka O., Fransen J., Avouac J. i wsp. Update of EULAR recommendations for the treatment of systemic sclerosis. Ann. Rheum. Dis. 2017; 76: 1327-1339.

12. Guiducci S., Bellando-Randone S., Bruni C. i wsp. Bostentan fosters microvascular de-remodeling in systemic sclerosis. Clin. Rheumatol. 2012; 31: 1723-1725.

13. Bellando-Randone S., Lepri G., Bruni C. i wsp. Combination therapy with bosentan and sildenafil improves Raynaud's phenomenon and fosters the recovery of microcascular involvement in systemic sclerosis. Clin. Rheumatol. 2016; 35: 127-132.

14. Cestelli V., Manfredi A., Sebastiani M. i wsp. Effect of treatment with iloprost with or without bosentan on nailfoldvideocapillaroscopic alternations in patients with systemic sclerosis. Mod. Rheumatol. 2017; 27: 110-114.
15. Cutolo M., Ruaro B., Pizzorni C. i wsp. Longterm treatment with endothelin receptor antagonist bosentan and iloprost improves fingertip blood perfusion in systemic sclerosis. J. Rheumatol. 2014; 41: 881-886.

16. Trombetta A.C., Pizzorini C., Ruaro B. i wsp. Effects of longterm treatment with bosentan and iloprost on nailfold absolute capillary number, fingertip blood perfusion and clinical status in systemic sclerosis. J. Rheumatol. 2016; 43: 2033-2041.

17. Miniati I., Guiducci S., Conforti M.L. i wsp. Autologus stem cell transplantation improves microcirculation in systemic sclerosis. Ann. Rheum. Dis. 2009; 68: 94-98.

18. Pinal-Fernandez I., Fonollosa-Pia V., Selva-O'Callaghan A. Improvement of the nailfold capillaroscopy after immunosuppressive treatment in polymyositis. QJM 2016; 109: 205-206.

19. Riccieri V., Vasile M., Macri V. i wsp. Successful immunosuppressive treatment of dermatomyositis: a nailfold capillaroscopy survey. J. Rheumatol. 2010; 37: 443-445. 


\section{$\mathbf{V} \mathbf{M}$ \\ VIA MEDICA \\ www.fr.viamedica.pl}

Ewa Wielosz

Katedra i Klinika Reumatologii i Układowych Chorób Tkanki Łącznej, UM w Lublinie

\section{Przydatność kapilaroskopii w ocenie zmian w mikrokrażeniu pod wplywem stosowanego leczenia}

Przedrukowano za zgodą z: Jeka S. (red.). Diagnostyka obrazowa chorób reumatycznych i monitorowanie leczenia biologicznego. Via Medica, Gdańsk 2019: 158-165.

Artykuł jest ttumaczeniem pracy: Wielosz E., The usefulness of capillaroscopy for assesmnet of microcirculation disturbances during treatment. Forum Reumatol. 2018 tom 5, nr 2: 65-69.

Należy cytować wersję pierwotna.

Piśmiennictwo znajduje się na stronach 68-69.

\section{STRESZCZENIE}

Badanie kapilaroskopowe jest nieinwazyjną metodą, która umożliwia ocenę mikrokrążenia u osób cierpiących na objaw Raynauda. Poza diagnotyką wczesnej twardziny układowej i chorób ze spektrum twardziny, badanie wykorzystywane jest w ocenie aktywności twardziny układowej oraz w monitorowaniu i ocenie skuteczności stosowa- nej terapii. Wykazano, że leki naczyniorozszerzające stosowane w leczeniu zaburzeń naczyniowych w przebiegu twardziny układowej istotnie wpływają na poprawę obrazu kapilaroskopowego, co wyraża się zwiększeniem liczby kapilar i zmniejszeniem dezorganizacji rysunku naczyniowego.

Forum Reumatol. 2019, tom 5, nr 2: 70-73

Słowa kluczowe: twardzina układowa; kapilaroskopia; leki naczyniorozszerzające
Adres do korespondencji: dr hab. n. med. Ewa Wielosz Katedra i Klinika Reumatologii i Układowych Chorób Tkanki Łącznej, UM w Lublinie e-mail: ewa.wielosz@wp.pl

\section{WSTĘP}

Badanie kapilaroskopowe jest nieinwazyjną metodą polegającą na obrazowaniu naczyń włośniczkowych warstwy brodawkowatej skóry w obrębie wału paznokciowego palców dłoni lub stóp pod mikroskopem stereoskopowym lub wideokapilaroskopem. Jest szczególnie przydatne we wczesnej diagnostyce twardziny układowej (TU), gdyż jest to choroba, w przebiegu której dochodzi do zaburzeń morfologii i funkcji drobnych naczyń krwionośnych, określanych jako mikroangiopatia. Poza wczesną diagnostyką TU, dzięki obrazowaniu mikrokrążenia naczyń wału paznokciowego, kapilaroskopia jest również wykorzystywana do oceny rozwoju głównych naczyniowych powikłań narządowych w przebiegu TU, takich jak tętnicze nadciśnienie płucne, owrzodzenia opuszków palców czy twardzinowy przełom nerkowy. Po- nadto na podstawie zmian widocznych w badaniu można ocenić aktywność choroby i stopień zajęcia narządów wewnętrznych, jak również monitorować efekty stosowanej terapii.

\section{KAPILAROSKOPOWA OCENA ZABURZEŃ MIKROKRAŻENIA}

Badanie kapilaroskopowe naczyń wału paznokciowego jest wykorzystywane w diagnostyce różnicowej pomiędzy pierwotnym objawem Raynauda a zaburzeniami mikrokrążenia we wtórnym objawie Raynauda, towarzyszącym układowym chorobom tkanki łącznej, zwłaszcza TU, ale również chorobom z grupy twardziny, takim jak: zapalenie skórno-mięśniowe, wielomięśniowe, mieszana choroba tkanki łącznej czy niezróżnicowana choroba tkanki łącznej [1]. U osób zdrowych 


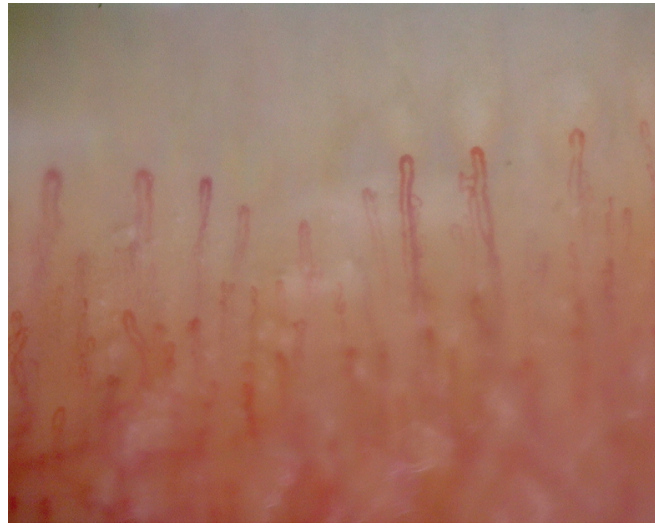

Rycina 1. Prawidłowy obraz kapilaroskopowy

obraz kapilaroskopowy charakteryzuje się regularnym, równoległym ułożeniem kapilar. W obrębie jednej brodawki skórnej powinno się znajdować od jednego do trzech naczyń, których kształt jest spinkowaty, a ich średnica nie powinna przekraczać $30 \mu \mathrm{m}$ (ryc. 1). W przebiegu TU w kapilaroskopii są widoczne charakterystyczne zaburzenia w mikrokrążeniu określane jako mikroangiopata typowa dla TU lub chorób z grupy twardziny. Termin mikroangiopatii obejmuje: poszerzenie pętli naczyń prowadzące do powstawania megakapilar, redukcję liczby naczyń, z obszarami beznaczyniowymi, obecność pętli rozgałęzionych i mikrowynaczynień czapeczkowatych oraz dezorganizację rysunku naczyniowego [2]. Cutolo i wsp. stworzyli podział zmian kapilaroskopowych w zależności od czasu trwania TU [3]. Wyróżnili zmiany wczesne, aktywne i późne. Według tej klasyfikacji megakapilary są typowe dla wczesnej mikroangiopatii twardzinowej i stwierdza się je rzadziej w późnym okresie choroby. W miarę postępu choroby występuje tendencja do redukcji naczyń, obecności obszarów beznaczyniowych i nowotworzenia naczyń, co jest typowe dla aktywnych zmian. W późnym stadium TU rzadziej występują megakapilary, a dominują głównie obszary beznaczyniowe i naczynia rozgałęzione [3] (ryc. 2 i 3). Ocena typu mikroangiopatii jest szczególnie istotna, gdyż na jej podstawie można określić aktywność i progresję choroby, a wielu przypadkach ocenić rokowanie. Wykazano, iż szybka redukcja liczby naczyń, odpowiadająca późnej mikroangiopatii twardzinowej w kapilaroskopii, jest czynnikiem gorszego rokowania, nasilonej progresji choroby i większego stopnia zajęcia narządów wewnętrznych [4].

Istnieją liczne doniesienia, w których wykazano związek pomiędzy zmianami ka-

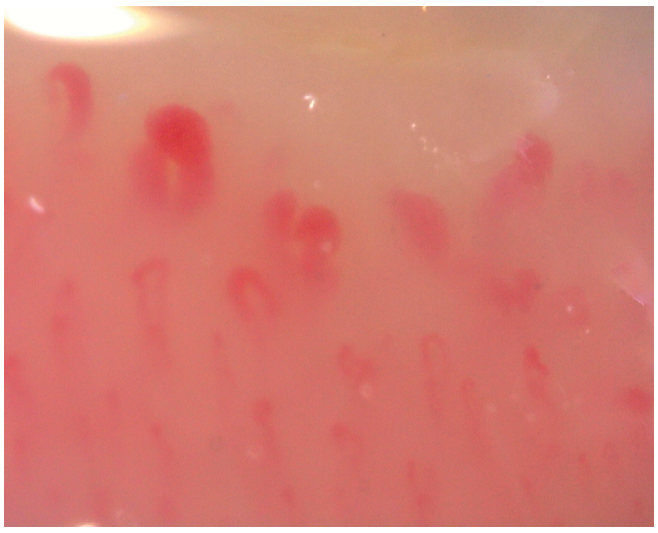

Rycina 2. Aktywna mikroangiopatia twardzinowa

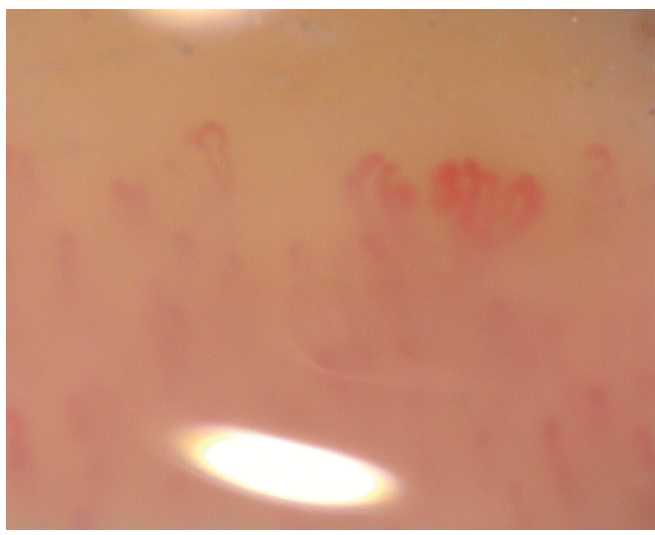

Rycina 3. Późna mikroangiopatia twardzinowa

pilaroskopowymi a zajęciem narządów wewnętrznych w TU. Szybka dynamika zmian, z tendencją do redukcji liczby naczyń i rozwojem mikroangiopatii typu późnego, zwłaszcza w ciągu pierwszych 3 lat choroby, koreluje z cięższym przebiegiem TU, ryzykiem rozwoju zmian śródmiąższowych w płucach i powikłań naczyniowych, takich jak owrzodzenia opuszków palców $[5,6]$. Paxton i wsp. na podstawie analizy piśmiennictwa $\mathrm{z}$ bazy Medline i Embase wykazali związek pomiędzy zmianami w kapilaroskopii (szczególnie utrata kapilar) a powikłaniami w przebiegu choroby, takimi jak owrzodzenia palców, zwapnienia i tętnicze nadciśnienie płucne [7]. Badanie kapilaroskopowe pozwala również przewidzieć ryzyko rozwoju powikłań naczyniowych (np. owrzodzenia opuszków palców). Wykorzystuje się w tym celu indeks rozwoju owrzodzeń $\mathrm{M} \times \mathrm{D}: \mathrm{N} 2$, w którym M oznacza liczbę megakapilar w $1 \mathrm{~mm}, \mathrm{D}$ - średnicę megakapilar - najszerszy wymiar kapilarny na szycie, N - całkowitą liczbę kapilar - liczba pętli naczyniowych w $1 \mathrm{~mm}$. Wykazano, iż jeśli indeks jest wyższy niż 2,96 , wynik ten koreluje 
ze zwiększonym ryzykiem rozwoju owrzodzeń w ciągu 3 miesięcy [8].

\section{POSTEPOWANIE W ZABURZENIACH MIKROKRAŻENIA W TWARDZINIE UKŁADOWEJ I W CHOROBACH Z GRUPY TWARDZINY}

W przebiegu TU dochodzi do przebudowy (remodelingu) w ścianie naczynia, co przyczynia się do rozwoju mikroangiopatii. Najwcześniej uszkodzeniu ulegają komórki śródbłonka. Aktywowane komórki endotelium uwalniają w nadmiarze czynniki naczyniowo-skurczowe, takie jak endotelina 1 (ET-1) czy śródbłonkowo-naczyniowy czynnik wzrostu (VEGF, vascular endothelial growth factor). Dochodzi także do niedoboru czynników naczyniowo-rozszerzających - prostacyklin i tlenku azotu. Efektem wzrostu uwalniania ET-1 oraz niedoboru tlenku azotu i prostacyklin jest skurcz i proliferacja ściany naczyń [9]. Obecnie stosowane leki w zaburzeniach mikrokrążenia w przebiegu TU wpływają pobudzająco na szlak prostacyklin lub tlenku azotu albo hamująco na szlak ET-1. Pierwszą grupę stanowią syntetyczne prostacykliny i ich analogi: epoprostenol, treprostynil czy iloprost, lub agoniści receptora prostacykliny - seleksypag. Druga grupa hamuje rozkład lub zwiększa produkcję tlenku azotu. Działanie wazodylatacyjne tlenku azotu odbywa się przy udziale cyklazy guanylowej i zwiększeniu aktywności cyklicznego guanozyno-3', 5'-monofosforanu (cGMP). Wykazano, że u chorych na TU aktywność fosfodiesterazy 5 - enzymu rozkładającego cykliczne GMP — jest zwiększona, a tym samym jest zwiększony rozkład tlenku azotu. Aby zahamować rozkład tlenku azotu, w leczeniu zaburzeń naczyniowych stosuje się inhibitory fosfodiesterazy 5, takie jak sildenafil lub tadalafil. Można też zwiększyć produkcję tlenku azotu poprzez zastosowanie aktywatorów cyklazy guanylowej (riociguat). Ostatnia grupa leków stosowanych w zaburzeniach naczyniowych hamuje uwalnianie ET-1 poprzez blokowanie receptorów dla endoteliny typu A i typu B na komórkach mięśni gładkich - są to nieselektywne i selektywne (macitentan, ambrisentan, bosentan) inhibitory receptora ET1-A [10]. Leki te mają szczególne zastosowanie w leczeniu epizodów objawu Raynauda u chorych na TU, owrzodzeń opuszków palców, tętniczego nadciśnienia płucnego, czy zapobieganiu tworzenia się nowych owrzodzeń palców u chorych na TU i w chorobach $\mathrm{z}$ grupy twardziny [11]. W konsekwencji leki te, działając silnie naczyniorozszerzająco, antypro- liferacyjnie, cytoprotekcyjnie i przeciwzakrzepowo, hamują remodeling $\mathrm{w}$ ścianie naczynia. W związku z tym zastosowanie preparatów naczyniorozszerzających istotnie zmienia obraz naczyń w badaniu kapilaroskopowym.

\section{ZMIANY W MIKROKRAŻENIU W OBRAZIE KAPILAROSKOPOWYM POD WPLYWEM STOSOWANYCH TERAPII}

W piśmiennictwie istnieje wiele doniesień przedstawiających dynamikę zmian w mikrokrążeniu ocenianym na podstawie badania kapilaroskopowego pod wpływem stosowanego leczenia naczyniorozszerzającego. W pracach tych sugeruje się istotną rolę kapilaroskopii w monitorowaniu skuteczności terapii chorych na TU. W jednym z badań oceniano prospektywnie obraz kapilaroskopowy w grupie 9 chorych na TU w trakcie rocznej terapii bosentanem $\mathrm{w}$ porównaniu z grupą 9 chorych na TU, którzy przez rok otrzymywali iloprost. Po 12 miesiącach leczenia bosentanem obraz kapilaroskopowy u 7 chorych uległ zmianie z mikroangiopatii twardzinowej typu późnego na mikroangiopatię typu aktywnego, u 2 chorych obraz nie uległ zmianie - obecne były zmiany o charakterze aktywnym i takie pozostały. $\mathrm{W}$ grupie chorych leczonych iloprostem zmiany kapilaroskopowe nie uległy zmianie $\mathrm{w}$ trakcie rocznej terapii. Wykazano, że blokery receptora ET-1 stosowane długotrwale zmieniają obraz kapilaroskopowy, co wyraża się zwiększoną liczbą kapilar, zmniejszoną liczbą naczyń rozgałęzionych oraz zmniejszoną dezorganizacją rysunku naczyniowego, a tym samym stabilizują mikrokrążenie oceniane za pomocą badania kapilaroskopowego [12].

$\mathrm{W}$ innym badaniu oceniano retrospektywnie wpływ leczenia bosentanem i sildenafilem oraz terapii kombinowanej na częstość ataków objawu Raynauda i na obraz zmian mikrokrążenia w kapilaroskopii. Przebadano 123 chorych na TU i oceniano obraz kapilaroskopowy w trakcie rozpoczęcia, po 3 i 6 miesiącach leczenia. $\mathrm{W}$ podsumowaniu stwierdzono, iż terapia skojarzona wykazuje istotnie lepszy efekt naczyniowy niż stosowanie tych leków osobno, w obrazie kapilaroskopowym zaobserwowano zwłaszcza zmniejszenie liczby mikroangiopatii typu późnego i deremodeling drobnych naczyń [13].

W kolejnej pracy oceniano wpływ terapii iloprostem oraz iloprostem i bosentanem na zmiany kapilaroskopowe u chorych na TU. Wpływ leczenia na mikroangiopatię twardzi- 
nową oceniano za pomocą kapilaroskopowego wskaźnika ryzyka rozwoju owrzodzeń skóry u chorych na twardzinę TU. Badanie kapilaroskopowe wykonano u 95 chorych na TU otrzymujących iloprost i terapię skojarzoną na pierwszej wizycie i po roku leczenia. Wykazano większą skuteczność terapii skojarzonej bosentanem i iloprostem w leczeniu owrzodzeń palców u chorych na TU, a zmniejszenie owrzodzeń było konsekwencją poprawy zmian w mikrokrążeniu w obrazie kapilaroskopowym, zmniejszenia dezorganizacji rysunku naczyniowego i poprawy w zakresie kapilaroskopowego wskaźnika ryzyka rozwoju owrzodzeń pod wpływem stosowanego leczenia [14]. Natomiast Cutolo i wsp. wykazali w trakcie 3-letniej terapii bosentanem i iloprostem istotne zwiększenie liczby naczyń i nieznaczne zmniejszenie obszarów beznaczyniowych w badaniu kapilaroskopowym u chorych na TU [15]. Podobne wyniki uzyskali Trombetta i wsp. w trakcie 4-letniej terapii skojarzonej [16]. Istnieją również doniesienia dotyczące zmian w mikrokrążeniu obrazowanym za pomocą badania kapilaroskopowego u chorych na ciężką postać uogólnioną TU, którzy otrzymali autologiczny przeszczep komórek macierzystych szpiku. W grupie 16 pacjentów chorych na postać uogólnioną TU, u których stwierdzono zmiany o charakterze późnej mikroangiopatii twardzinowej, u 6 zastosowano przeszczep autologiczny komórek macierzystych szpiku, 10 natomiast otrzymywało cyklofosfamid w dawce $1 \mathrm{~g} /$ miesiąc przez 6 miesięcy, a następnie $50 \mathrm{mg} / \mathrm{dobę} \mathrm{p.o.} \mathrm{przez} 6$ miesięcy. Badania kapilaroskopowe wykonywano co 3 miesiące. W ciągu 2-letniej obserwacji już po 3 miesiącach po przeszczepie komórek w obrazie kapilaroskopowym stwierdzono zmianę z mikroangiopatii typu późnego na typ aktywny. W grupie chorych otrzymujących cyclofosfamid nie stwierdzono zmian w kapilaroskopii w trakcie leczenia [17]. Dynamikę i istotną poprawę zmian kapilaroskopowych pod wpływem stosowanego leczenia również można zaobserwować w innych chorobach układowych tkanki łącznej, takich jak zapalenie skórno-mięśniowe czy wielomięśniowe. Wykazano, iż w tej grupie chorych z mikroangiopatią typową dla twardziny leczenie immunosupresyjne istotnie zwiększa gęstość kapilar i poprawia ich rozmieszczenie $[18,19]$.

\section{PODSUMOWANIE}

Badanie kapilaroskopowe jest nieinwazyjnym badaniem, umożliwiającym ocenę zaburzeń mikrokrążenia, które poza wczesną diagnostyką twardziny układowej i chorób ze spektrum twardziny oraz oceną aktywności choroby i stopnia zajęcia narządów wewnętrznych, może być wykorzystywane w monitorowaniu i ocenie skuteczności prowadzonego leczenia. Leki naczyniorozszerzające stosowane w leczeniu twardziny układowej i chorób ze spektrum twardziny istotnie zmieniają obraz kapilaroskopowy, co wyraża się poprzez zwiększoną liczbę kapilar i zmniejszoną dezorganizację rysunku naczyniowego oraz hamowanie remodelingu ściany naczynia. Terapia skojarzona lekami naczyniowymi istotnie wpływa zarówno na poprawę mikrokrążenia ocenianego w badaniu kapilaroskopowym, jak i na zmniejszenie kapilaroskopowego wskaźnika ryzyka owrzodzeń, co w konsekwencji istotnie zapobiega powstawaniu owrzodzeń palców i innych powikłań naczyniowych w twardzinie układowej. W grupie chorych z mikroangiopatią chorób ze spektrum twardziny (zapalenie skórno- i wielomięśniowe) terapia immunosupresyjna istotnie wpływa na poprawę zmian kapilaroskopowych. 